\title{
Model Of Disability Learning in Islamic Education at Inclusive School Malang, Indonesia
}

\author{
Zulfi Mubaraq $^{\mathrm{a}^{*}}$, Fachrul Kurniawan ${ }^{\mathrm{b}}$, Uril Bahruddin ${ }^{\mathrm{c}}$, Siti Lailatus Sholihah ${ }^{\mathrm{d}}$ \\ a,b,c,d Lecturer at UIN Maulana Malik Ibrahim Malang Indonesia \\ a*email: zulfi@pips.uin-malang.ac.id
}

Article History: Received: 10 November 2020; Revised 12 January 2021 Accepted: 27 January 2021; Published online: 5 April 2021

\begin{abstract}
Education is the most basic need for every human being, even children with special needs also really need education. Given the importance of education for all, education for children with special needs is facilitated by disability or inclusive-based classes. The inclusive class model as an alternative recommended by the government to serve children with special needs. This study aims to find out the extent of planning, implementation, evaluation, and impact points of learning implementation Islamic education in inclusive schools at Malang city. This research used a qualitative approach, a type of case study with a multi-site study design. The data collected is organized, interpreted, and analyzed in cross-site cases and analyses. research instruments used include interviews, observation, and documentation. The results are Planning standard of islamic education learning in the inclusion class is the same as other schools using the 2013 curriculum which includes syllabus and learning planning. It's just that the special assistant teacher made a design of teaching materials that are appropriate to the situation of each child with special disabilities. Implementation Standard, there are at least many models, including inclusion classes, used regular full inclusion classes with simplified indicators, cluster classes, and pull out using individual learning programs. Evaluation conducted by disability schools is to separate between normal students and those with special disabilities who differ in the description of the indicators. Another model in this school the difference between normal students and those with special needs, the assessment system of students with special needs.
\end{abstract}

Keywords: Model, Disability Learning, Islamic Education, Inclusive School.

\section{Introduction}

Many teachers, especially Islamic Religious Education teachers, are less able to handle students with special needs, which results in them having to be transferred to inclusive schools. This is due to a lack of knowledge in dealing with students with special needs so it is not uncommon for students with special needs to be transferred to schools that specifically handle students with special needs. It is not uncommon also in rural schools, if there are children with special needs, they tend to get discriminatory treatment so that many of them do not go to school, this is also because in the village of inclusion schools that can handle children with special needs on average are in the city center and with this it is not easy to reach by the child's parents, so with this research it is hoped that teachers, especially Islamic religious education teachers, can have knowledge if they find children with special needs so that this becomes an added value for Islamic religious education teachers in schools if they find children with special needs. So that the researchers want to research inclusive schools that have experience dealing with inclusive children.

Islam is one of the religions where education is very important without differentiating between humans (education for all). The obligation to study knowledge is not limited to some or certain groups, but is a necessity for all Muslims, whether male, female, normal or disabled [].Demanding knowledge is compulsory for every Muslim []. Read by (mentioning) the name of your Lord Who Created (1) He has created man from a clot of blood (2) Read it, and it is your God who is most gracious (3) who teaches (humans) through kalam (4) He teaches man what is not known (5) []. I did not create jinn and humans but so that they worship Me[].

However, it turns out that one of the problems facing the Indonesian education world is the weak learning process. In the learning process, children are not encouraged to develop character and thinking skills. As a result, when our students leave school, they are smart theoretically, but they have poor application. This certainly shows that what is desired in the above law has not been fully achieved[]. Therefore, in accordance with the mandate of Government Regulation Number 19 of 2005 concerning National Education Standards, one of the standards that must be developed is a process standard. Process standards are national education standards related to the implementation of learning in educational units to achieve graduate competence (Government Regulation of National Education Standards). 
Learning in inclusive schools is carried out as learning in regular classes, but at certain times the learning is modified in such a way as to suit the individual capacities of the inclusive students. If necessary, the inclusive students are withdrawn from the regular class and placed in individual rooms to get special guidance from the accompanying teacher. Thus, students who have obstacles in their learning due to physical and psychological dysfunction can choose one of the choices of inclusive schools or special schools. Physical and psychological dysfunction that can significantly interfere with the learning process if you have to study in a regular school or an inclusive school, you should choose a special school [].

In the inclusive class there is a diversity of students with various backgrounds, abilities, abilities, and capacities; from extraordinary levels of ability and capacity to students with special needs. The educational services provided simultaneously cause the relationship between all students to take place interactively to understand, understand, accept differences in order to increase empathy, sympathy, tolerance, and cooperation between them. Inclusive student can still study in regular classes with the provision of accompanying teachers with them in addition to class teachers.

For inclusive students, at certain times they are given service in a special room, separated from normal students, and handled by a special teacher / companion with learning activities in areas that are difficult if they have to be delivered together with normal students. This special activity is also intended to provide therapy as needed. For this reason, teachers who have competencies comparable to special school teachers are needed to become companion teachers, or as guest teachers to accompany children with special needs [].

Aim this study is to find out the extent of planning, implementation, evaluation and impact points of learning implementation Islamic education in inclusive schools elementery school Ketawanggede and Sumbersari at Malang city, Indonesia. The title paper is Model of Disability Learning in Islamic Education at Inclusive School Malang, Indonesia.

\section{Literature Review}

\section{Disability Learning and Inclusive School}

The autism that has good academic, communication and emotional skill are able to go to integrated school accompanied by guidance teacher. But in practice, inclusive education in Indonesia is inseparable from stakeholders ranging from government and institutions such as schools, educators, school environment, community and parents to support the goal of inclusive education itself. Adequate infrastructure also needs to be given to the school that organizes inclusive education for an efficient and effective students understanding learning-oriented of inclusive education. In short, every child has the same opportunity in education, yet for special education which is aimed at student with special educational needs [].

Many of the themes reflect the learning outcomes of the QCF learning disability qualifications introduced in 2011. Personalised services, quality of life and inclusion for all and key issues are covered in this new edition. Topics include: legislative frameworks person-centred thinking: implementing person-centred approaches in health and social care self-directed support and personalisation intimate lives: sexuality and people with learning disabilities family matters: working with parents with learning disabilities [].

Several studies have been conducted in India to determine the prevalence of learning disabilities in school children which has been reported to be 3-10 per cent among students population. The present study was conducted to find out prevalence of specific developmental disorder of scholastic skills in students of classes VII to XII and to find out feasibility of screening tool in Chandigarh, India. A total of 38 students were found to be having specific developmental disorder of scholastic skills in phase I, that gave a prevalence of 1.58 per cent. Majority had mixed type of errors on SLD battery. There were more boys diagnosed with specific learning disability. Teacher's screening instrument had high sensitivity (90.385) and specificity (94.68). The findings of our study conducted in community, showed that specific learning disability was not identified even till later age. The screening instrument thus could be used by teachers to suspect students with specific learning disability [].

Vaughn, Bos \& Schumn who explain the placement of children with disabilities in inclusive schools can be done with various learning models as follows: (1) Full inclusion regular class. Children with disabilities learn with other children (normal) throughout the day in regular classes using the same curriculum. (2)Regular class with clusters. Children with disabilities learn with normal children in regular classes in special groups. (3) Regular class with pull out. Children with disabilities learn with normal children in regular classes but at certain times are pulled from the regular class to the resource room to study with a special supervisor. (4) Regular class with cluster and pull out. Children with disabilities learn with normal children in regular classes in special groups, and at certain times are pulled from the regular class to the resource room to study with a special supervisor. (5) Special class with various integrations. Children learning in special classes at regular schools, but in certain fields can 
study with normal children in regular classes. (6) Full special class. Children wandering about studying in special classes at regular schools [].

\section{Islamic Education}

Islamic Character Education and national insight in the industrial era 4.0 is very important to convey to students in facing the challenges of globalization. This article aims to illustrate the problem of Islamic education and nationality insight in the industrial era 4.0 and to formulate educational management on these issues. Through studying the literature, this qualitative method found that: First, Islam as a religion of peace gives peace to all beings in nature. Second, Islam as a religion rahmatan lil alamin is a moderate religion with regard to aqeedah, sharia, and morals. Third, Islam arranges a peaceful life with communities outside of Islam politely and with respect for human values. The Prophet Muhammad SAW is a plenary figure who must be followed by students in a harmonious life between religion and nationality. Indonesia as a country based on Pancasila guarantees the religious life of its citizens and upholds human values. Therefore the results of this study conclude that Islamic character education and nationalist insight in the industrial era 4.0 are very important [].

The analysis of Covid-19 impact on Islamic Higher Education (IHE). this article have a few significant implications for the science and practice of online education and its perspectives on the IHE system. Prospects of online education of students have been offered during Covid-19. The main recommendations are the following: to organize training courses of online education methods for lecturers; to organize in-depth training courses of online education methods for lecturers of non-pedagogical specialties; the university's management should provide constant monitoring of the satisfaction of students and lecturers of the online education organization for the accumulation of statistical data in the dynamics [].

Increasing the phenomenon of juvenile delinquency and the deterioration of the quality of learners' character, the strengthening of the function of education as a character shaper re-emerges and becomes an urgent demand for the implementation of the Character Building Strengthening program through the implementation of the main values (religious, nationalist, independent, mutual cooperation and integration), and in this study the most fundamental value is the value of religious character. Therefore, as an effort to build a superior generation of national civilization in terms of intellectual, spiritual, emotional balanced with human nature, it is necessary to have religious character education for students with the achievements of Moral Knowing, Moral Feeling and Moral Doing. This study aims to analyze the model of religious character education in MAN 1 Lebong, a stateowned aliyah madrasa or Islamic school. This study uses qualitative methods conducted in the 2019/2020 Academic Year. Done by describing what programs, how they are implemented and how the model of religious character education in MAN 1 Lebong. Sources of data are Madrasah Heads, Teachers (both those who get additional assignments as Deputy Heads, Subject Teachers, and Counseling Guidance Teachers) and students. Data collection uses observation, interviews, and documentation. Data analysis methods consist of data reduction, data presentation, conclusion and verification. The results showed that the religious character education model in MAN 1 Lebong had not been effective, most students were at the stages of moral knowing and moral feeling, but the achievement of moral doing was not fully implemented by students [].

\section{Method}

This research used a qualitative approach, a type of case study with a multi-site study design of planning, implementation, evaluation and impact points of learning implementation Islamic education in inclusive schools elementery school Ketawanggede and Sumbersari at Malang city, Indonesia.. The data collected is organized, interpreted, and analyzed in cross-site cases and analyzes. Research instruments used include: interviews, observation and documentation [].

In this research describe Miles and Hubberman's model which consists of three elements. The data analysis process steps in this study are as follows []:

(1) Data reduction. This step refers to the process of selecting, focusing, simplyfing, and abstracting the data that appears in the field notes, or transcriptions of data that may be derived from interviews, observations or other qualitative research tools." Reducing data refers to the process of summarizing, selecting the main things, focusing on the important things, looking for themes and patterns and removing unnecessary. Thus the reduced data provides clearer data and makes it easier for researchers to collect data regarding the implementation of process standards in learning islamic religious education at inclusive schools; (2) Data display. After reducing the data, the next step is to display the data or present the data. Data presentation can be done in the form of brief descriptions, charts, relationships between categories, flowcharts, and the like, usually data that is often used in qualitative research with narrative texts. The aim is to simplify information, from complex information to simple information so that it is easy to understand the meaning. The presentation of data regarding is divided into four areas or parts, namely the implementation of learning standards which refer to the four implementation standards, program success, and their implications for schools; (3) Verification and Conclusion is the third step in qualitative data 
analysis. The author examines and analyzes the research data using the developed mindset, then draws conclusions from the data. Drawing conclusions must answer the formulation of the research problem.

The validity of the data so that the data collected is accurate and get direct meaning to the actions in research. its validity was tested through triangulation of data technically, source, and time []: (1) Triangulation technique. Technique triangulation is done by checking data obtained from the same source with different techniques. Technique triangulation is done by asking the same thing with different techniques, namely by interviewing observation and documentation. The data obtained through interviews will be tested by observation and documentation. (2) Triangulation of sources. Triangulation of sources is done by asking the same question through several sources. Related to this research, the data sources are the principal, curriculum representatives, representatives of and students.

(3) Time triangulation. Triangulation of time is used as the assumption that time often affects the credibility of the data. This means that data collection is carried out on various occasions, morning, afternoon, and evening. In practice, the researcher checks the data from interviews and documentation. Furthermore, the results of the interview then the researcher checked with the results of the observations that the researcher did during the research period to find out how the implementation of the process standards in Islamic religious education learning at inclusive schools. Then the data obtained were described, categorized, where the views were the same, different and specific from several sources. The data were analyzed to produce a conclusion, then agreement was asked for some of these sources.

This method is used by the author to explore data relevant to the research topic, namely the Implementation of Process Standards in Learning Islamic Religious Education in Inclusion Classes at the elementery school Ketawanggede and Sumbersari 1 Malang.

\section{Result and Discussion}

1. Regarding lesson planning at the elementery school Ketawanggede, shadow teachers make learning programs in accordance with the 2013 curriculum, namely the lesson plans used by all students, both students with special needs and normal students. It's just that, there is a simplification of indicators for students with special needs. Learning planning at elementery school Sumbersari 1, shadow teachers make learning programs according to the situation of students or what is called PPI (individual learning programs) for students with special needs. Meanwhile, normal students use learning planning as in the 2013 curriculum.

2. Implementation Standard, there are at least a number of models, including: inclusion classes, used regular full inclusion classes with simplified indicators, cluster classes and pull out using individual learning programs. The implementation of learning at elementery school Ketawanggede is a full inclusion class model where students with needs are included in receiving regular class learning with other normal students. Meanwhile, elementery school Sumbersari 1 uses the cluster and pull out class model where children with special needs participate in learning in one class with other normal students. However, at certain times they are withdrawn from the regular class to the source class to study with a special companion teacher.

3. The evaluation of the Islamic religious education learning process for students with special needs is the same as the evaluation for ordinary normal students. The assessment that the teacher uses is the 2013 curriculum assessment. This is due to the absence of a special curriculum for students with special needs. The question of evaluating students with special needs at elementery school Ketawanggede and Sumbersari 1 given is different from normal students. The Islamic religious education teacher provides evaluation questions from the agency so that the form of the problem is different from normal students because the evaluation questions for students with special needs are simplified even more. In addition, supervisor teacher participates in assessing students with special needs.

\section{Conclusion}

The standards for the learning process of islamic religious education at the elementery school Ketawanggede and Sumbersari 1 Malang are in accordance with the learning standards that have been applied in the National Education Standards (SNP) and are in accordance with their minimum components. In its implementation, each school is able to adapt to the needs of their respective schools, without reducing the predetermined standards. Learning becomes more focused on achieving basic competencies in accordance with the characteristics of students with special needs. So that the learning objectives can be achieved, the teacher is easy to improve the learning process. If there are results that are less than optimal, the competence of graduates can be achieved optimally. The conformity of planning standards with implementation standards determines the success of the learning process, make use of the available resource space specifically for students with special needs so that students with special needs do not concentrate perfectly 


\section{References}

Quran, Abasa Surah: 1-2.

Hadith Ibnu Majah no.224.

Quran, Al-‘Alaq Surah: 1-5.

Quran, Al-Żāriyāt Surah: 56.

Kholid Fathoni, Muhammad (2005). Pendidikan Islam dan Pendidikan Nasional [Paradigma baru]. Jakarta: Depag RI.

Government Regulation Number 19 of 2005 National Education Standards of Indonesia..

Bhargava \& Pathy (2011). Perception of Student and Teachers about Teaching Competencies. Journal of Contemporary Research, Vol. 1, No. 1, 2016), Hlm 77.

Yatmiko, Febri; Banowati, Eva and Suhandini, Purwadi. "Implementasi Pendidikan Karakter Anak Berkebutuhan Khusus.” Journal of Primary Education, Vol. 4, No. 2, 2015), Hlm. 77-84.

Imaniah, I., \& Fitria, N. (2018). Inclusive Education for Students with Disability. SHS Web of Conferences, 42 , 00039. https://doi.org/10.1051/shsconf/20184200039

Learning Disability Today. (2016). ISSN: 16130073 (March), N/A. Retrieved from https://www.learningdisabilitytoday.co.uk/government-policy/Learning Disability Today, 2016.

Landau, P. (2015). Annual Report 2015. Bulletin of Medieval Canon Law, 32(1), xi-xii. https://doi.org/10.1353/bmc.2015.0008

Latif, Muktar dkk, Orientasi Baru Pendidikan Anak Usia Dini, Jakarta: Prenada Media Grub.

Purwanto, Y. (2020). Islamic Character Education and Nationalism Insight of Students in the Era of Industry 4.0. International Journal of Psychosocial Rehabilitation, 24(4), 5471-5485. https://doi.org/10.37200/ijpr/v24i4/pr201643

Supriyatno, T., \& Kurniawan, F. (2020). A New Pedagogy and Online Learning System on Pandemic COVID 19 Era at Islamic Higher Education. In Proceedings - 2020 6th International Conference on Education and Technology, ICET 2020 (pp. 97-101). Institute of Electrical and Electronics Engineers Inc. https://doi.org/10.1109/ICET51153.2020.9276604

Rahman, M., \& Aliman, A. (2020). Model Analysis of Religious Character Education in State-owned Islamic School. Journal of Educational Management and Leadership, 1(1), 14-21. https://doi.org/10.33369/jeml.1.1.14-21.

Moleong, .Lexy J. (2013). Metodologi Penelitian Kualitatif. Bandung: Remaja Rosda Karya.

Brundett, Mark dan Rhodes, C. (1998), Resesarch Educational Leadership and Management, London: SAGE Publications.

Sugiyno (2013). Metode Penelitian Kombinasi (Mixed Methods). Bandung: Alfabeta. 